19 神経疾患に於ける平衡維持機構と重心動㯰 (III 動摇速度, 動摇移行距離, 動摇面皘の 分析)

$$
\begin{aligned}
& \text { O大久保 不, 渡辺 觔 } \\
& \text { 小高 修司, 堤内 邦应 } \\
& \text { 奥野 秀次 }
\end{aligned}
$$

（東医歯大）

平衡障害患者の早期䛦断もしくは予後の判定法として 重心動摇を中心に分析が盛んに行なかれている.神経疾 患の平衡障害例には，しばしば開脚起立は出来るが，口 ンベルグ足位をとらせると転倒する例がある。ロンベル グ徵候は1846年にロンベルグが，神経疾患特に答噵障害 や末梢神経障害の患者にロンベルグ足位をとらせ閉眼す る事により著明に障害が観察されると報告した。この事 上り今日 “肉眼的神経疾患の钼察法”飞用いられてい る.それ故, 此の方法を用いて精度の高い重心動摇計で 重心動摇を検査する事は䛊差（S.D. 比）をいたずらに 增大させる危険性が西る。そこで神経疾患で平衡障害を 有する片麻㾇 45 例, パーキンソン15例, 小脳失調 21 例飞 比較的立ち易い足位をとら世, 開眼, 閉眼時の疾患别あ るいは障害部位別の重心動摇を, 動摇速度, 動摇移行距 離, 動㜔面積なごを指摽として分析を行い，2〜3の知見 を得たので報告する。

万 法: 各疾患の重心動摇の勒跡データー処理は, 開 眼, 閉眼に於ける $\mathrm{x} \cdot \mathrm{Y}$ 座標の時間変化についてその平 均值を求め, この中心からの偏りを2 乗平均值の平方根 で評価した。 又, $\mathrm{x}$ 座標 (左右) の振巾 $\mathrm{x} と \mathrm{y}$ 座標 （前後）の振巾 $\mathrm{Y}$ との䅡 $\left(\mathrm{mm}^{2}\right)$ を用いて面積の評価 とした. 移行距離は $\mathrm{x} \cdot \mathrm{y}$ 座標の時間变化のデーターを 数値微分し, $\mathrm{X}$ 万向, $\mathrm{Y}$ 万向の速度を計算し, この速 度の大きさを 2 乘平均值の平方根で評価する方法を用い た.な悢, 生データーのノイズの影響を少くするため数 值微分には低域通過型微分フィルタ (Lanczosの3次 微分フィルタ)を用いた。

結 果: 正常者の走位に上る動摇移行距離の変化を口 ンベルダ, 開脚 $5 \mathrm{~cm}, 10 \mathrm{~cm}, 30^{\circ}$ 扇形足位, $60^{\circ}$ 扇形足 位で比皎すると，ロンベルグ原法では X 軸のバラッキ が大きく移行距離も長い。次いで $60^{\circ}$ 扇形足位が $\mathrm{Y}$ 軸 そパラッキ, 当然のことながら, 開脚では $\mathrm{Y}$ 軸が $\mathrm{X}$ 軸 に比して平均值が高い値を示す，この事を考慮に入れ て, 神経疾患の開眼, 閉眼時の $\mathrm{X}$ 軸, $\mathrm{Y}$ 軸動摇速度を 検討すると, 各疾患とも閉眼時飞 Y 軸方向への速度が 增大寸る傾向が認められ，障害部位により增大方向への 包配などに差位が認められた。な经動摇移行距離之面積 との相関性についても併せて検討を行った。

\section{Square Drawing Test 一西手書き法の成綪一}

\author{
○兼定 啓子, 関谷 透 \\ 田中 宗昭, 八木 幹忠 (山口大)
}

目 的: め事い症, 体平衡失調症の椮查法の内, 書字 検榃, とくに福田の遮眼書字法は上肢にあらわれる偏筒 傾向, 振戦現象を表示するのに誠に適した方法で, 各検 查室で広く用いられている。が，検查所見を得るのに， 定性的ばかりでなく,さらに各種パラメーターを定量的 に表示するために Square Drawing Test を開発した. その書き方の内, 特に両手書き法ならびにその成績を報 告する。

方 法: 検查用紙は, 一辺 $40 \mathrm{~mm}$ の正方形を， $15 \mathrm{~mm}$ 間隔で縦に 4 コ，40mm 間隔で横に3コ, 合計 12 の 四角形を薄く印刷したものを用いる・被験者は, この印 刷された四角形の線上を忠実に竞どりこれを開眼時， 遮眼時儿各々程に 4 二の四角形を描くよう指示する. 右 手書き時は, 左上隅より描き始め (始点), 下方 $\rightarrow$ 右方 $\rightarrow$ 上方 $\rightarrow$ 左方の順で始点に 戻る(これを終点とする). 連続法とし，途中でペンを上げさせない。左手書き時 は，右手書をと対称形の筆順とする.開眼時，遮閉眼時 に描かれた四庙形を計測するパラメーターは，1）偏書 角度，2）各辺の長さ，3）始点一終点間距離 (離開度), 4) 全長, 即 5 No. 1 の始点之 No. 4 の始点間距離之 し，左右共で合計44項目である。さらに，書線の乱れの 有無沈ついて記載する。

成 綪: 健常者群 (50名) そついて, 各パラメーター の成績性，1）偏書角度は，左右共に $6^{\circ}$ 以内であり，右 手書き時は大半が右偏書傾向を示方が, 左手書き時は, 特定の㴜書傾向はない，2）各辺の長さは，遮眼時《は すべて短縮化する傾向があり，とくに右手書き時侸著 である.3）離開度は, No. 1 から No. 4 とつれて, 次 第に大きくなる。4) 全長は，開眼時には $16.5 \mathrm{~cm} て ゙$ あるが，遮眼時には左右共飞短縮する。次に，失調性疾 患群では, 偏書角度は增大し，各辺のばらつきが大きく

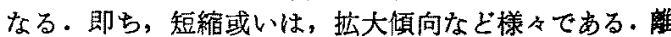
開度は, 健常群に比べて,さらに增大傾向を示寸。また 描楾の振戦が強くあらかれる。

まとめ：健常群と各種疾患群と比較検討を試及ると， 各々有意差はみられるが，との程度の有意差で異常とす るのかは, 倘, 検討中である.今回, 健常者群のSDT 両手書き法と，その成績を供覧し， $2,3 の$ 臨床例との此 較検討を試み若千の考察を加党て報告した。 